\title{
Identification and Characterization of Protamine1 Gene in Aceh Cattle
}

\author{
Teuku Z. Helmi ${ }^{1,5}$, Muhammad Hambal ${ }^{2}$, Sugito Sugito ${ }^{3}$, Rumi S. Zamzami ${ }^{3}$ Rusli Rusli ${ }^{3}$, and Muslim Akmal $^{4,5 *}$ \\ ${ }^{1}$ Laboratory of Biochemistry, Faculty of Veterinary Medicine, Universitas Syiah Kuala, Banda Aceh, Aceh, Indonesia; \\ ${ }^{2}$ Laboratory of Parasitology, Faculty of Veterinary Medicine, Universitas Syiah Kuala, Banda Aceh, Aceh, Indonesia; \\ ${ }^{3}$ Laboratory of Clinic, Faculty of Veterinary Medicine, Universitas Syiah Kuala, Banda Aceh, Aceh, Indonesia; \\ ${ }^{4}$ Laboratory of Histology, Faculty of Veterinary Medicine, Universitas Syiah Kuala, Banda Aceh, Aceh, Indonesia. \\ ${ }^{5}$ Center for Collaborative Research Animal Biotechnology and Coral Reef Fisheries (CCR ANBIOCORE), USAID-SHERA.
}

\begin{abstract}
Naturally, the fertility of Aceh cattle has declined and caused huge losses in the development of Aceh cow germplasm. Several genetic-based studies have been carried out in Aceh cattle, including characteristics of genetic diversity using microsatellite DNA and its relationship to body weight in Aceh cows, but there is no research on genomics that is closely related to fertility, especially fertility in aceh cows. Previous studies have revealed a correlation between fertility with the expression of several genes involved in spermatogeneses such as Protamines (PRM 1, 2, and 3) and Transition Nuclear Proteins (TNPS 1 and 2). This study aims to identify the $P R M 1$ gene that plays an important role in spermatogenesis and the fertility status of Aceh cattle. This research was carried out using 10 Aceh cattle testes taken from slaughterhouses, followed by DNA isolation, amplification of the PRMI gene, DNA sequencing, and DNA base sequence analysis. The result showed that the nucleotide sequences of aceh cattle PRM1 gene did not differ from the PRM1 gene from Bos taurus and Bos indicus in the GeneBank. Analysis of protein sequences showed that PRM1 in Aceh cattle sperm is rich in the amino acid arginine, which is $36.92 \%$. From this study, it can be concluded that the PRMI gene from Aceh cattle is identical to the PRMI gene from Bos taurus and Bos indicus both at the DNA sequence level and at the protein sequence.
\end{abstract}

Keywords: Aceh cattle, PRM 1 gene, quality of sperm.

\section{Introduction}

Aceh cattle are one type of livestock that are widely developed by the people of Aceh as a livelihood. Aceh cattle through the decision of the Minister of Agriculture of the Republic of Indonesia Number 2907/Kpts.OT.140/06/2011 has been established as a native Indonesian cattle family and as national germplasm that needs to be conservative [1]. Some of the advantages of Aceh cattle are that they have high fertility, are more resistant to adverse environmental conditions, quickly adapt to new environments, and breed quickly [2]. One of the adverse effects due to the high exploitation of Aceh cows is the decline in genetic quality [3].

The main problem faced in the development of Aceh cattle is the low quality of seedlings caused by the occurrence of inbreeding and management of livestock maintenance that is not good [3]. The existence of negative selection makes an important contribution to the decline in genetic quality [4]. A number of genetic-based studies have been carried out in Aceh cows, including characterization of genetic diversity using microsatellite DNA [5], and characterization of genetic diversity of microsatellite DNA and its relationship to body weight in
Aceh cows [6], but there are no studies on genomics that are closely related to fertility, especially fertility of Aceh bulls.

Naturally, the fertility power of Aceh cattle decreases, causing huge losses to the Aceh cattle germplasm development program. The use of good quality semen is very important for the success of reproductive technology such as artificial insemination and embryo transfer. According to Ferraz et al. [7], infertility in bulls is characterized by a reduced ability of spermatozoa to fertilize oocytes and support early embryonic development. The technique commonly used to evaluate cow sperm quality is to look at the concentration, morphology, and motility of spermatozoa. This simple evaluation has not been able to predict the actual level of cattle fertility, due to the quality of genetic material contained in sperm. Fatehi et al. [8] states that sperm DNA damage does not affect oocyte fertilization or completion of the embryo division sequence, but inhibits embryo formation due to apoptosis.

During spermiogenesis, haploid spermatids undergo a series of changes in chromatin composition and density [9]. Meanwhile, in the round spermatid, the bond between deoxynucleic acid (DNA)-histone will be replaced by

\footnotetext{
* Corresponding author: akmal.kh@unsyiah.ac.id
} 
transition proteins, whereas in elongated spermatid, the transition protein will be replaced by protamine [10]. Transition proteins are the main proteins found in chromatin in condensed spermatids which are believed to play an important role in the replacement of histone and chromatin condensation during spermatogenesis in mammals [11].

During fertilization, spermatozoa play an important role in the development of the embryo by providing oocyte activation factors, centrosomal components, and a paternal chromosome. Protamine (PRM) is a basic nucleus protein with small molecular weight contained in the head of spermatozoa $[12,13]$, which is important in the packaging of sperm DNA [14] and plays an important role in spermatogenesis and quality of sperm [15]. The results of the study by Ganguli et al. [16] showed that the high PRM1 mRNA expression was closely related to the good quality of semen produced by bulls.

Based on the problems above, this study was conducted aiming to identify and characterize the PRMI gene in Aceh cattle as well as to find out the differences in the PRM1 gene sequence in several Aceh cattle with other types of cattle. The results of this study are expected to be the basis for the selection of males with good fertility so that they can be applied in reproduction technology to support central and local government programs in developing Aceh cow germplasm.

\section{Materials and Methods}

\subsection{Time and Place of Research}

This research activity includes field activities and laboratory activities. Field activities were carried out through taking data and testes of Aceh cattle in the Slaughterhouse (RPH) of Keudah in Banda Aceh City. Laboratory activities for total DNA extraction from Aceh cattle testes, amplification of the $P R M 1$ gene, were carried out at the Research Laboratory of the Faculty of Veterinary Medicine at Syiah Kuala University, sequencing of the nucleotide sequence of the PRMI gene was carried out at First Base Singapore through the services of PT Genetics Science Indonesia.

\subsection{Research Samples}

This study uses 10 testes of Aceh cattle which are local cows from Aceh Province. Sampling is carried out immediately after the cattle are slaughtered, then sample preparation is carried out to separate the cauda epididymis from other parts of the testis. The sample is put in a sterile tube, then stored in an icebox to be taken to the Research Laboratory of the Faculty of Veterinary Medicine, Syiah Kuala University. Samples were stored at $-20{ }^{\circ} \mathrm{C}$ until DNA extraction was carried out.

\subsection{Research Materials}

The materials used in this study include DNA isolation kits using PureLink ${ }^{\circledR}$ Genomic DNA Kits from Invitrogen, PCR master mix reaction using Platinum TM
Hot Start PCR Master Mix, Ultrapure DNAse / RNAse Free Distilled Water from Invitrogen, SYBR® Safe DNA Gel Stain, 100bp DNA ladder from Cleaver Scientific, Buffer Tris-Borate EDTA 10x. Primary sequences of partial specific PRM genes that were designed using the Primary-Blast Program on the NCBI website: https://www.ncbi.nlm.nih.gov, with the reference gene GU394047.1.

\subsection{Procedure}

\subsubsection{Total DNA extraction from the Aceh Cattle Semen}

Total DNA extraction from Aceh cattle testes using PureLink ${ }^{\circledR}$ Genomic DNA Kits, the extraction procedure is carried out following the work in the manual issued by the factory that manufactures the kit. The crushed testicle sample is put into a $25 \mathrm{mg}$ microtube, then $180 \mu \mathrm{L}$ PureLink ${ }^{\circledR}$ Genomic Digestion Buffer and $20 \mu \mathrm{L}$ Proteinase $\mathrm{K}$ are added to the tube. The microtubes are then shaken using a mini-mixer and incubated at $55^{\circ} \mathrm{C}$ for 4 hours or until lysis, then spindown for a few seconds centrifuged for 3 minutes at maximum speed to pick up cell pellets. Then $20 \mu \mathrm{L}$ RNase A was added to the cell lysate, vortexed and incubated at room temperature for 2 minutes, then $200 \mu \mathrm{L}$ PureLink ${ }^{\circledR}$ Genomic Lysis / Binding Buffer was added as much as $200 \mu \mathrm{l}$, and vortexed again. Then to lysate added $200 \mu \mathrm{L}$ 96-100\% ethanol.

Furthermore, $640 \mu$ l was transferred into PureLink ${ }^{\circledR}$ Spin Column, then centrifuged at a speed of 10,000 xg, then carried out the Washing step by adding $500 \mu \mathrm{l}$ Wash Buffer I and centrifuged at a speed of 10,000 $\mathrm{xg}$ for 3 minutes. The spin column was transferred to the new collection tube, then added $500 \mu \mathrm{l}$ Wash Buffer II and centrifuged at $10,000 \mathrm{xg}$ for 3 minutes. Furthermore, PureLink ${ }^{\circledR}$ Spin Column was placed in a $1.5 \mu \mathrm{l}$ microtube, and added with $50 \mu \mathrm{l}$ PureLink ${ }^{\circledR}$ Genomic Elution Buffer, then incubated at room temperature, then centrifuged at maximum speed for 5 minutes. The results of DNA isolation can already be used for amplification.

\subsubsection{Analysis of Gene Expression with Realtime $P C R(q P C R)$}

Total DNA extracted was carried out by amplification of the PRMI gene, by PCR reaction using Platinum TM Hot Start PCR Master Mix (Invitrogen, California, United States), with a total reaction of $25 \mu \mathrm{L}$ reaction mix consisting of $12.5 \mu \mathrm{L}$ Platinum TM Hot Start PCR Master Mix, $0.5 \mu \mathrm{L}$ forward primer, $0.5 \mu \mathrm{L}$ reverse primer, and 5 $\mu \mathrm{L}$ DNA template $(10 \mathrm{ng})$, then added with $6.5 \mu \mathrm{L}$ $\mathrm{ddH} 2 \mathrm{O}$.

The PCR program was arranged as follows: initial denaturation at $94{ }^{\circ} \mathrm{C}$ for 2 minutes; denaturation temperature at $94{ }^{\circ} \mathrm{C}$ for 30 minutes, annealing at $59{ }^{\circ} \mathrm{C}$ for 30 seconds, elongation at $72{ }^{\circ} \mathrm{C}$ for 45 seconds, continued extension at $72{ }^{\circ} \mathrm{C}$ for 5 minutes, and postelongation for 5 minutes at $72{ }^{\circ} \mathrm{C}$ reaction amplification carried out as many as 35 cycles. 
Tabel 2. The 65 amino acid sequences of the PRM1 gene isolate compared to the access code M18395.1, with the Aceh cow PRM1 gene isolate.

$$
\begin{aligned}
& \nabla^{232} \\
& \text { T MARYRCCLTH SGSRCRRRRR RRCRRRRRRF GRRRRRRGEE GPSLGAGARE LGRGWGFGLC *SVLV } \\
& \text { T MARYRCCLTH SGSRCRRRRR RRCRRRRRRF GRRRRRRGEE GPSLGAGARE LGRGWGFGLC *SVLV } \\
& \triangle 283
\end{aligned}
$$

\begin{tabular}{|c|c|c|c|c|c|c|c|c|c|c|c|c|c|c|c|c|c|}
\hline & & Ala & Cys & Glu & Phe & Gly & His & Leu & Met & Pro & Arg & Ser & Thr & Val & $\operatorname{Trp}$ & Tyr & Total \\
\hline Comparison sequences & $96.1):$ & 4.62 & 7.69 & 4.62 & 3.08 & 15.38 & 1.54 & 7.69 & 1.54 & 1.54 & 36.92 & 6.15 & 3.08 & 3.08 & 1.54 & 1.54 & 65 \\
\hline equences & : & 4.62 & 7.69 & 4.62 & 3.08 & 15.38 & 1.54 & 7.69 & 1.54 & 1.54 & 36.92 & 6.15 & 3.08 & 3.08 & 1.54 & 1.54 & 65 \\
\hline
\end{tabular}

Table 3. Composition of 65 amino acid PRM1 gene isolates compared to access code M18395.1, with Aceh cattle PRM1 gene isolates.

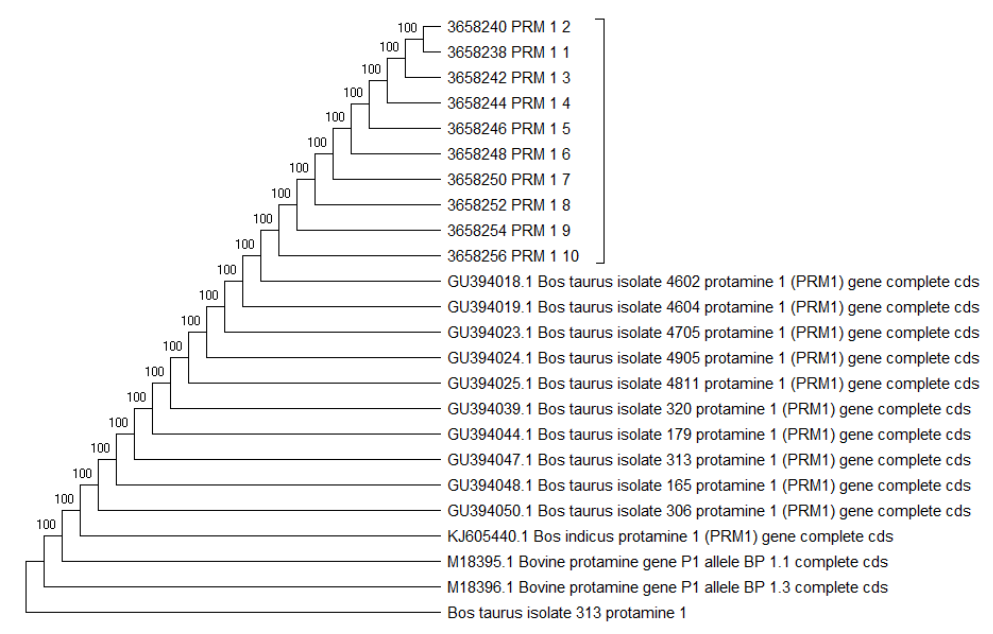

Figure 2. Results of phylogenetic construction of the Aceh cattle PRM1 gene with comparative isolates from GenBank, using the Neighbor-Joining method with the Kimura 2 Parameter model and 1000x bootstrap.

The results showed that protamine gene disorders cause disruption of chromatin density, sperm DNA damage, and male infertility. In addition, the presence of heterozygous single nucleotide polymorphism in the $P R M 1$ gene causes infertility in men [20]. Decreasing the number and localization of PRMI causes defects in the structure of sperm chromatin, thereby reducing the fertility of bulls [14].

\section{Conclusion}

From this study, it can be concluded that the PRMI gene from Aceh cattle is identical to the PRMI gene from Bos taurus and Bos indicus both at the DNA sequence level and at the protein sequence.

\section{Acknowledgments}

"This paper is supported by USAID through Sustainable Higher Education Research Alliances (SHERA) Program-Center for Collaborative Research Animal Biotechnology and Coral Reef Fisheries (CCR ANBIOCORE)".

\section{References}

1. Mukhtar, Jamaliah, Saumar H: Phenotype diversity of female aceh cattle in BPTU- HPT Indrapuri. Jurnal Ilmiah Peternakan. 2015; 3(2):34-38.

2. Umartha BA: Mengenal Karakteristik Sapi Aceh. Banda Aceh: Balai Pembibitan Ternak Unggul (BPTU) Sapi Aceh Indrapuri. 2005.

3. Putra WBP, Sumadi, Hartatik T, et al.: Seleksi pada sapi Aceh berdasarkan uji performans di BPTU-HPT sapi Aceh Indrapuri. JITRO. 2016; 3(2):72-80.

4. Hardjosubroto W: Aplikasi Pemuliabiakan Ternak di Lapangan. Jakarta: Gramedia Widiasarana. 1994.

5. Abdullah MAN: Hubungan Kekerabatan Sapi Aceh dengan Menggunakan Daerah Displacement-loop. Agripet. 2008; (2):9-14.

6. Sari EM, Yunus M, Jianlin H, et al:: Characterisation polymorphims of genotype microsate llite in association with body weight of Aceh cattle. JITV. 2013; 18(3):220-226.

7. Ferraz PA, Burnley C, Karanja J, et al: Factors affecting the success of a large embryo transfer program in Holstein cattle in a commercial herd in the southeast 
region of the United States. Theriogenology. 2016; 86(7):1834-1841.

8. Fatehi AN, Bevers MM, Schoevers E, et al.: DNA Damage in Bovine Sperm Does Not Block Fertilization and Early Embryonic Development But Induces Apoptosis After the First Cleavages. J Androl. 2006; 27:176-188.

9. Steger K: Transcriptional and translational regulation of gene expressions in haploid spermatids. Anat Embryol. 1999; 199, pp.471-478.

10. Steger K, Failing K, Klonisc T, et al.: Round spermatid from infertile men exhibit decreased protamine-1 and -2 mRNA. Hum Reprod. 2001; 16(4), pp.709-716.

11. Ye Y, Zhang Y, Unni E, et al:: Abnormal spermatogenesis and reduced fertility in transition nuclear protein 1-deficient mice. Proc Natl Acad Sci U S A. 2000; 97(9):4683-4688.

12. McKay DJ, Renaux BS, Dixon GH, et al:: Human sperm protamines. Amino-acid sequences of two forms of protamine P2. Eur J Biochem. 1986; 156, pp.5-8.

13. Rooney AP, Zhang J: Rapid evolution of a primate sperm protein, relaxation of functional constraint or positive Darwinian selection? Mol Biol Evol. 1999; 16, pp.706-710.

14. Dogan S, Vargovic P, Oliveira R, et al.: Sperm Protamine-Status Correlates to the Fertility of Breeding Bulls. Biol Reprod. 2015; 92(4):92.
15. Akmal M, Aulanni'am, Widodo MA, et al.: The important role of protamine in spermatogenesis and quality of sperm. Asian Pac. J. Reprod. 2016; 5(5):357360 .

16. Ganguly I, Gaur GK, Kumar S, et al.: Differential expression of protamine 1 and 2 genes in mature spermatozoa of normal and motility impaired semen producing crossbred Frieswal (HF Sahiwal) bulls. Res Vet Sci. 2013; 94:256-262.

17. Krawetz SA, Dixon GH: Sequence Similarities of the Protamine Genes: Implications for Regulation and Evolution. J Mol Evol. 1988; 27:291-297.

18. McRae MP: Therapeutic Benefits of L-Arginine: An Umbrella Review of Meta-analyses. Journal of Chiropractic Medicine. 2016; 15(3):185-189.

19. Al-Ebady AS, Hussain SO, AL-Badry KI, et al.: Effect of adding arginine in different concentrations on some physical properties of poor motile bull sperms during different months. Journal of Veterinary Medicine and Animal Health. 2012; 4(9), pp.130-135.

20. Iguchi N, Yang S, Lamb DJ, et al:: An SNP in protamine 1: a possible genetic cause of male infertility? $\mathrm{J} \mathrm{Med}$ Genet. 2006; 43:382-384. 